\title{
The more things change, the more they stay the same? The impact of formalising policies on personalisation in paid domestic work - the case of the service voucher in Belgium
}

\author{
Anna Safuta ${ }^{1,2^{*}}$ and Beatriz Camargo ${ }^{3}$
}

\footnotetext{
* Correspondence: anna.safuta@unibremen.de

${ }^{1}$ Fonds de la recherche scientifique, FNRS, Brussels, Belgium

${ }^{2}$ Present address: University of Bremen, Unicom, Office 7.1090, Mary-Somerville-Str. 7, Bremen 28359, Germany

Full list of author information is available at the end of the article
}

\begin{abstract}
Belgium had a long tradition of direct informal employment in paid domestic work, which has undergone formalisation through the introduction of the 'service voucher system'. This policy triangulates the employment relationship between workers and clients through introducing third-party employing agencies, and guarantees workers' access to labour and social security rights. Up until now, most international studies of paid domestic work have focused on direct and privatized worker-employer relationships (Anderson, Doing the dirty work?: The global politics of domestic labour, 2000); Hondagneu-Sotelo, Domestica: Immigrant workers cleaning and caring in the shadows of affluence, 2001); (Lutz, The New Maids: Transnational women and the care economy, 2011); Moras (Sociology Mind, 3(3), 248-256, 2013); (Romero, Maid in the U.S.A., 1992), This literature has shown that paid domestic work often features 'personalised' (emotionally-loaded) worker-employer relationships. The goal of this article is to analyse the impact of the introduction of the service voucher system on personalisation processes affecting paid domestic work in Belgium. Is personalisation bound to disappear with the sector's formalisation or is it intrinsic to paid domestic work? We show that personalisation is not threatened by formalisation policies which do not challenge the structural inequalities underpinning paid domestic work (and to which personalisation develops as a remedy). In the Belgian case, the service voucher policy did not challenge the crucial role of personalisation for finding and keeping jobs, as well as improving working conditions. The article shows that personalisation is an informal social protection strategy which developed in the exploitative conditions of informality, but is likely to survive formalising policies. Indeed, formalisation did not eliminate the need for personalisation, as it did not substantially improve working conditions in the sector, failed to recognise workers' qualifications and to challenge the gendered and migrantized character of domestic work employment.
\end{abstract}

Keywords: Domestic work, Domestic workers, Belgium, Formalisation, Personalisation, Migrant workers, Informal social protection, Service voucher 


\section{Introduction}

This paper investigates the impact of formalisation policies on personalisation in housework and/or domiciliary care provided by migrant workers (hereafter 'paid domestic work'). ${ }^{1}$

Most studies of paid domestic work have so far focused on worker-employer relationships within the informal economy. These studies have demonstrated that such employment relationships are often highly personalised (Arnado, 2003; Borgeaud-Garciandia \& Lautier, 2011; Hondagneu-Sotelo, 2001; Moras, 2013; Rollins, 1985). In this context, several authors have claimed that doing away with personalisation is a necessary step to limit the occupation's exploitative elements (Anderson, 2000; Aubert, 1956; Coser, 1973; Rollins, 1985). In line with this idea, studies have shown that certain categories of domestic workers resist personalisation in a bottom-up effort to professionalize the occupation (Lutz, 2011; Rollins, 1985; Romero, 1992). Conversely, other authors have shown that domestic workers often appreciate, expect and even use personalisation to their advantage (Arnado, 2003; Hondagneu-Sotelo, 2001).

Market or state-driven initiatives formalising the provision of paid domestic work (that is taking it out of informality) often include the triangulation of previously bilateral worker-employer relationships, through the introduction of an employing third-party. Following the logic of modernization, such triangulating formalisation is expected to result in the decrease of the frequency and importance of personalisation (Mendez, 1998, p. 117). Meagher (1997), Mendez (1998) and Du Toit (2013) have however convincingly demonstrated that formalisation does not necessarily eliminate personalisation processes. Their conclusions have been formulated in the context of market-driven formalisation, which makes Belgium an interesting case study. Indeed, formalisation in Belgium occurred through the introduction of the service voucher scheme, which is a highly subsidized public policy effort to take the housecleaning sector out of informality (Marx \& Vandelannoote, 2014). In the last twenty years, several European countries have introduced similar policies aimed specifically at formalising previously informal paid domestic work (Carbonnier \& Morel, 2015), which renders our findings comparable and even generalizable under certain conditions.

The voucher system allows households in Belgium to purchase weekly housework services (excluding care) from an authorized agency. Before the introduction of the service voucher, paid domestic work (at least housecleaning) in Belgium was predominantly provided informally. Informal work involves unmediated employment relations, in which the person who benefits from the work is simultaneously the employer or a close relative of the employer (as when children hire a domestic worker to help their parents).

Contrary to a similar scheme introduced in neighbouring France (the Chèque Emploi Service Universel, CESU), the Belgian service voucher does not allow households to become private employers, but triangulates previously bilateral employment relationships: workers are no longer employed directly by the households in which they work, but by authorized agencies. The agencies then provide cleaning services to interested clients who pay with vouchers.

The service voucher system is heavily subsidized by public authorities, including through tax breaks ${ }^{2}$ offered to clients. Despite subsequent reforms which increased the price of a voucher (which was initially lower than the price of an hour of cleaning in 
the informal sector) and reduced offered tax breaks, service vouchers remain very advantageous to clients (when compared with informal domestic work).

Under the voucher system, domestic workers have access to labour and social security rights (unemployment allowance, invalidity and retirement pension, paid holidays, sick leave, maternity leave, etc.). In order to access the voucher system, a worker must however be allowed to work legally in Belgium or have Belgian citizenship. Undocumented workers cannot thus use formal employment in the voucher scheme as a way to regularise their stay in Belgium. Thus, the service voucher created a two-tier domestic service market through confining undocumented migrant domestic workers to informality.

Undocumented third-country nationals working informally in paid domestic work were only able to enter the voucher system once their stay in Belgium was regularised. Besides one-off regularisation campaigns (in 2000, 2001 and 2009) and regularisation through family reunification, the Belgian migration regime offers very few possibilities to settle in Belgium. Work permits have to be renewed annually and are very hard to obtain in the case of employment in low skilled work. Contrary to the two previous regularisation campaigns, the 2009 campaign foresaw the possibility to apply for a stay permit based on proofs of current employment in Belgium or a promise thereof. Third-country nationals who applied based on a service voucher contract were the most numerous group of applicants to use this procedure. The 2009 regularisation wave contributed to the boom of the voucher service in 2009-2010 due to the arrival of new workers.

When they decide to switch from informal to formal employment, documented migrant workers are generally motivated by the perspective of accessing social security rights. Sometimes the transition is also the result of pressure from private employers ${ }^{3}$ or of friends and family's advice. The voucher system, which can only be used for housework (cleaning, ironing, doing laundry and grocery shopping), ${ }^{4}$ coexists with needs-based formal domestic services including elderly care, as well as with housework and/or care provided without a legal contract (i.e. informally). The Belgian case is thus uniquely interesting, as it allows to examine simultaneously the working and living conditions of domestic workers who joined the voucher system, and those who cannot or do not want to enter it. In this article, we redefine personalisation as a process through which the professional emotional work expected from workers as part of their job becomes blurred with the private emotional work which is part of everyday non-professional life (Safuta, 2017). Based on our fieldwork results, we then show the impact of formalisation on personalisation in paid domestic work.

We combine the results of two separate qualitative studies of paid domestic work in Belgium to demonstrate that the introduction of the service voucher scheme did not reduce the frequency and crucial role of personalisation in this occupation. Personalisation will remain key within paid domestic work as long as formalisation policies do not challenge the structural inequalities to which personalisation develops as an individual remedy. Personalisation remains unavoidable because it is a crucial way of finding and keeping jobs, as well as of improving working conditions.

The paper starts with a brief description of the methodologies of data collection and analysis. The second section adds some context through describing formal and informal paid domestic work in Belgium, and the profiles of the migrants working in it. The 
third section discusses our findings, together with the theory behind it. We finish with some concluding remarks.

\section{Methodology}

The contribution brings together the results of two complementary studies of the domestic work sector in Belgium. The first study examined the consequences of the formalisation of paid domestic work in the Brussels region. The conclusions of this study are based on interviews conducted between 2011 and 2014 with domestic workers, clients of the service voucher system, and authorized agencies. Most of the 30 domestic workers participating in the research were first generation migrants, out of whom 18 were nationals of non-EU countries, nine were $\mathrm{EU}$ citizens ${ }^{5}$ and three were Belgian nationals with a foreign background. Research participants were selected randomly, guided by the concern of including a varied scope of nationalities and life situations. South-American workers are well represented among participants. This is mainly due to the researcher's nationality, which generated a better access to workers' networks, but also to the representativeness of this group in the informal market and its recent entry in the formal labour market. ${ }^{6}$ Semi-structured interviews with participants were completed by participant observation in an NGO dealing with migrants - mostly undocumented, as well as interviews with government representatives, trade unionists and NGO activists. Fieldwork was then analysed from the point of view of employment relationships, transitions to formal employment in the voucher system and clients' conceptions of cleanliness and domestic work.

The second study investigated paid domestic work (care and/or housework) provided informally by migrants in private households across Belgium and Poland, as well as the role this kind of provision plays in the economies, gender and welfare regimes of the two countries. Data collected in Belgium consisted of in-depth narrative interviews with 24 migrant cleaners and/or carers (some of whom were interviewed more than once), as well as with 12 private employers (some of whom had also experiences as service voucher clients). Interview material has been completed by expert interviews, as well as observations on public transport, social media and other places of socialization for migrant domestic workers. The interviews have been conducted in 2012-2016, mainly in the multilingual city of Brussels, although some respondents were also living and/or working in smaller localities in Dutch-speaking Flanders or French-speaking Wallonia. Among migrant domestic workers interviewed in Belgium, Poles ${ }^{7}$ and Filipinos were the most represented national groups due to the researcher's ability to interview respondents in their respective native/official language. ${ }^{8}$ Collected material has been coded thematically, which resulted in the inductive identification of three overarching themes: questions of control over the labour process and autonomy on the job; workers and employers' emotional work; and both parties' 'doing identity' practices.

Combining the results of these two studies presents the advantage of including the experiences of four groups of migrant domestic workers: those who work formally within the voucher scheme after experiencing informal domestic service work; those who did not experience informal work before entering the voucher system; those who cannot enter it; and finally those who could enter the scheme (because they are EU citizens or can work legally in Belgium), but chose not to do so. The first group includes Polish and Romanian respondents who worked in Belgium before nationals from their 
countries were allowed free access to the Belgian labour market as EU citizens (on 1 January 2009 and 1 January 2014, respectively), ${ }^{9}$ as well as previously undocumented third country nationals who benefited from the regularisation campaigns in 2000, 2001 or 2009 or from family reunification, including some of the Filipinx and South-American respondents. The second group includes younger Polish citizens who arrived in Belgium from 2009 onwards and directly accessed formal employment in the voucher system. Theoretically it also includes EU citizens from the EU15, who have free access to the Belgian labour market, but are much less present in the voucher system than Polish and Romanian citizens. The third group is composed of undocumented third country nationals. The last group mainly includes EU respondents who keep working informally. As this article will show, personalisation plays a similarly important role for these four categories of workers.

\section{Change and continuity in paid domestic work in Belgium}

Belgium has a long tradition of informal direct employment in paid domestic work. Until 2014, Belgian households could legally employ a live-out domestic worker without paying social security contributions, as long as the services provided were housework and did not exceed four hours a day and $24 \mathrm{~h}$ in total (in one or several households) per week.

In 2001, Belgian authorities introduced the service voucher (titres-services in French, dienstencheques in Dutch), a scheme allowing households to formally purchase weekly cleaning services from agencies authorized to become employers. Authorized agencies include individuals, non-profit organizations, for-profit companies (including temporary work agencies), and local public authorities (such as local employment agencies and social assistance centres). Most migrant domestic workers are employed by for-profit private companies and temporary work agencies (Gerard, Romainville, \& Valsamis, 2014, p. 32). Many private companies are managed by foreigners or Belgian nationals from foreign origin, attracting newly arrived migrants from the same national/ethnic background. Almost all of the first study's respondents worked within this kind of ethnic-oriented for-profit enterprises.

Due to vouchers' competitiveness compared with prices in the informal market, many households switched to vouchers, while keeping the worker they used to employ informally. One of the main policy objectives behind the introduction of the voucher system was to reduce the then widespread private informal employment of domestic workers. The voucher was aimed more particularly at dual-earner households with children, because authorities considered that other categories of employers (such as the frail elderly) accessed housework and care services through other formal channels (Sansoni, 2009).

The voucher policy did not challenge the feminization and migrantization of the domestic service workforce. In 2013, 97.4\% of service voucher workers were women and $28.1 \%$ were not Belgian (among which 20.1\% came from EU-27 countries and $8 \%$ were non-EU nationals) (Gerard et al., 2014, p. 37). ${ }^{10}$ According to a 2015 assessment, non-Belgians and Belgians with a foreign background represent together $48 \%$ of all service voucher workers (SPF Emploi \& CECLR 2015, p. 93). In the Brussels region, the sector is even more migrantized than in the rest of the country: the same assessment shows that less than $1 \%$ of all service voucher workers in Brussels have a Belgian background (SPF Emploi \& CECLR 2015, p. 94). 
Employers/clients are (elderly or not) single men or single women, (elderly or not) heterosexual and homosexual couples, with children or not, and sons or daughters of elderly beneficiaries. In the case of heterosexual couples employing a cleaner, the 'managers' of these cleaning services are usually female partners. This is reflected by the fact that all interviewed migrants interact mostly (some even exclusively) with the female partner. Even when both partners are professionally active, male and female partners in heterosexual couples are not 'interchangeable' with regard to domestic work. When the female partner is unable to carry out domestic chores over a longer period of time, a transfer of housework to the male partner is not even discussed. The introduction of the service voucher has only strengthened the outsourcing of domestic work as the default strategy in case of the female partner's unwillingness/inability to provide this type of work (Safuta, 2017).

The 'democratization' of domestic services through the affordability of service vouchers resulted in a diversification of the class profiles of employers. However, although the service voucher is used by families at different disposable income levels, the proportion of households using the scheme increases with income and education levels (Marx \& Vandelannoote, 2014, p. 9).

'Peripherally white' migrant domestic workers from Poland are preferred to their non-white counterparts from elsewhere (Safuta, 2018). This preference can be explained by the 'comfortable alterity' they embody. On the one hand, Polish women (white, Catholic, European) are not 'too different' from Belgian employers, which minimizes potential cultural and religious tensions and reduces the emotional work required from employers in terms of domesticating differences within the private sphere of their homes and everyday routines. On the other hand, Polish women are not 'too similar', which maintains (often implicit) interpersonal and structural hierarchies between workers and employers. Such hierarchies are more easily threatened by native domestic workers. In conjunction with other factors, such as geographical proximity and wage differentials between the two countries, comfortable alterity explains the popularity of Polish domestic workers in Belgium since the late 1980s and the increasing popularity of their Romanian counterparts today.

Interestingly, some interviewed domestic workers were employed informally by other domestic workers. Polish service voucher worker Katarzyna came to Belgium to care for the child of a service voucher employee who is an acquaintance from her home town. Similarly, the first job in Belgium of Filipina informal cleaner Rosie was to care for the children of other Filipina migrants.

Despite the introduction of the voucher system, informal employment in domestic services persists. While some workers do not have access to formal work, others choose to opt out. Domestic workers employed informally are mainly undocumented migrants, without access to stay and work permits in Belgium, but also EU citizens who arrived in Belgium before the opening of the Belgian labour market to workers from their country of origin and subsequently kept working informally. This might be due to a refusal of the working time limitations in the formal scheme, ${ }^{11}$ shift work $^{12}$ with a relative of a friend, an unwillingness to pay income taxes and social security contributions, or to renounce a retirement or invalidity pension in the country of origin. In such cases, it is not uncommon for Polish domestic workers, for instance, to have access to health insurance in Poland (on the basis of retirement or invalidity). When in Belgium, they use their European Health Insurance Card for medical emergencies and pay out-of-pocket when outpatient care is needed. 
Workers with a temporary or circular migratory perspective are focused on primary accumulation: they want to earn money in order to reinvest in their country of origin (e.g. buy a house, invest in a business or in their children's education) instead of gaining social rights Belgium. ${ }^{13}$ With time, social security and the right to a retirement pension might gain in importance in their eyes. Most migrant domestic workers consider the transition to the voucher system as a positive development, mainly due to their newly gained formal worker status.

The impact of formalisation on workers' identity is limited. Workers' perception of themselves and of their work changes very little after entering the voucher scheme. It is partially due to the fact that formalisation does not change work practices and relationships with employers/clients. Workers continue to work in the same households - which now became 'clients' in place of 'employers' - often keep the same schedules and perform the same tasks, despite some of these tasks not being allowed under the service voucher system. Some voucher workers even continue to provide care as they used to do informally, despite the fact that vouchers can formally be used only for housework. They do not consider that their work has changed, or see themselves more as professionals than before.

The regularisation of migratory status has bigger consequences in terms of empowerment and self-perception than entering formal employment in the voucher system (Camargo Magalhães, 2016). When entry into formal employment occurs simultaneously with the regularisation of migratory status, both are blurred. For instance, the Brazilian Silvana, who lived 12 years as an undocumented migrant before being regularised in 2009, recalls:

- What changed in your life when you first started working in the voucher agency?

- What changed? ... Well, today I am not scared to lose my job [laughs], because I trust myself and know I will find another one, because now I have papers. You have more... More rights, because when you don't have papers, not everyone agrees to hire you in the shadow market. Mostly, you have more self-confidence. I have more confidence to face problems (...). Since I'm documented, I'm braver to face things.

-But which aspect of this change comes from working for a voucher agency? Because this is about having papers, isn't it?

- Hum, yeah... At the agency girls are super nice! And then, how to say it, we feel secure. Like, if something happens, I know that the agency is there to help us... That's for me the main change with the agency: if I need them, they're there to help me.' (Silvana, from Brazil, documented, voucher employee since regularisation).

Silvana's words show that she experiences becoming documented and entering the voucher system as one big transition. The major change in her life came from regularisation: becoming documented empowered her to 'be braver' and to possibly quit her job if need be. She also lists the advantages of employment in the voucher system: a new, less solitary work environment and feeling supported by the agency's staff. Although these aspects are 
significant, they fall within the larger framework of Silvana's empowered 'new life' as a documented migrant.

We will now review the impact of the service voucher scheme on a central element of paid domestic work, in Belgium and elsewhere: personalisation.

\section{Personalisation in paid domestic work with regard to formalisation State of the art}

Personalisation is a concept used in a variety of disciplines, including management studies (Murthi \& Sarkar, 2003; Surprenant \& Solomon, 1987), social policy (Needham, 2014; Xie, Hughes, Sutcliffe, Chester, \& Challis, 2012), economic sociology and the sociology of work (Borgeaud-Garciandia \& Lautier, 2011). Summarizing the ways in which each of these disciplines approaches the phenomenon, personalisation can be broadly described as a process which goes against two tendencies generally characterizing modern transformations of the world of work: standardization (of the labour process and of the produced good/service) and emotional distancing (from clients). Studies of paid domestic work have defined personalisation in a narrower way, as a unilateral or bilateral process affecting the interpersonal relationships between workers and private employers/clients. Romero and Pérez defined it as the process through which one of the parties to the employment relationship seeks emotional connection with the other (Romero \& Pérez, 2016, p. 179). Personalisation has also been defined as the 'strong personal attachment' (Lutz, 2011, p. 95) or 'close personal relationship' (Moras, 2013, p. 248) which often develops between domestic workers and members of employing households.

Most studies of domestic services point to the frequency of personalised relations in private employment (Arnado, 2003; Borgeaud-Garciandia \& Lautier, 2011; Hondagneu-Sotelo, 2001; Moras, 2013; Rollins, 1985). Personalisation often manifests as workers and/or employers declaring that there are like family to each other. This 'part of the family' (Anderson, 2000), 'elective kinship' (Lutz, 2011) or 'fictive kin' (Karner, 1998) tendency is particularly strong in relationships with elderly beneficiaries (Kaufmann, 1997, p. 104). Our respondent Ewa, who works in Belgium since 1995 (first informally, then in the voucher system) perfectly sums up such 'kinning processes' (Baldassar, Ferrero, \& Portis, 2017): 'When you work for someone for a long time, the employer trusts you completely and you sometimes have the impression that you are part of the family'.

Paid domestic work consists of work within the private realm of employers/clients' households. Deprived of the possibility to appropriate the workspace (as it is someone's else home) (Molinier, 2009, pp. 116-119), workers invest emotionally in the relationship with employers and/or care receivers, as it is often the only avenue for professional satisfaction, recognition and gratification (Aubert, 1956, p. 158). Personalisation helps fight the loneliness and social isolation stemming from the solitary character of work in private households, exacerbated in the case of live-in workers and more generally migrant workers (Ambrosini, 2012, p. 8; Hondagneu-Sotelo, 2001, pp. 194-207). Domestic workers who migrated autonomously are vulnerable in this respect, as they cannot compensate low levels of job satisfaction by overinvesting into their private life, at least at the beginning of their migratory 'career', when they do not yet have a network in the host country. Personalisation is also an avenue for getting emotional and identity rewards from a socially devalued job (Aubert, 1956, p. 158; Solari, 2006, p. 312). 
Additionally, paid domestic work (in particular when it involves body work) involves physical proximity between workers and beneficiaries of their services. Given this closeness and the often very intimate character of involved tasks, workers and beneficiaries are sometimes unable or unwilling to maintain the distinction between private and professional emotional investment. It seems personalisation is also a strategy some employers use to deal with the guilt of having a domestic worker (Molinier, 2009, p. 120).

Combining the insights of our two empirical studies and existing theoretical approaches from a variety of disciplines, we redefine personalisation as the blurring of professional and private emotional work (Safuta, 2017): involved individuals do not know anymore whether they provide emotional work because they are expected to do so as part of their role as domestic workers or employers/clients (professional emotional work), or because they want to (as part of any individual's emotional work).

\section{Personalisation in practice}

In line with previous conclusions by Arnado (2003) and Hondagneu-Sotelo (2001), workers interviewed in the framework of our two studies value personalisation. They generally experience impersonal, distant relationships as emotionally painful and de-humanizing. Most of our respondents insist (in a slightly bragging tone) that members of the households in which they work (the elderly person they take care of on a daily basis, but also young children or even pets in the households they clean on a weekly basis) respond to them better than to their own relatives.

Personalisation is intensified among undocumented workers, whose situation is more precarious than that of EU citizens working informally. Graziela says that after her visa expired and she became undocumented, she felt 'as if she did not exist'. She explains that she survived the very long, lonely hours of work in a suburban Brussels house (ten months, first as a live-in, then as a live-out) thanks to the energy she received from the toddler she was taking care of:

'I think the person who gave me a lot of energy and a lot of hope was the small baby,

Léa. Because it was a very isolated job. There were no neighbours, so it was a bit...

[...] I wasn't seeing anyone except my boyfriend [that she met right after arriving in

Belgium] and my little baby, my little baby Léa, I was working a lot.' (Graziela, from

Chile, previously undocumented, obtained a stay permit through marriage)

Workers are usually expected to adapt to employers' preferences in terms of personalisation, lest they be considered 'cold' or on the contrary 'exhausting'. Care-giving in particular comes with a strong expectation of emotional investment. Both elderly beneficiaries and their relatives understand good care as including an important emotional work component. When beneficiaries are elderly, this expectation also holds in cases of housework, including in the voucher system. As a consequence of personalisation, domestic workers providing housework to elderly beneficiaries are often expected to start providing care as employers get older, in particular in the case of long-term employment relationships. It is then difficult for workers to refuse, because a refusal results in termination or at least the deterioration of the employment relationship.

Stenia has been cleaning the apartment of one of her employers since arriving in Belgium 25 years ago. As her employer got older and less fit, Stenia's duties have been 
slowly transitioning from housework to housework with care, despite Stenia making clear that she does not intend to fulfil the employer's expectations ('They ask me "Hopefully you will be with us until we die", Stenia, from Poland, informal domestic worker since the 1990s, benefits from an agricultural retirement pension in Poland, does not plan to join the voucher service). Since several years now, Stenia has been giving showers to the employer. The Polish domestic worker had also moved in with this employer for two weeks when the elderly lady was recovering from an operation.

However, while personalisation is emotional investment, invested emotions are not necessarily positive. Most interviews with employers feature descriptions of domestic workers past and present who are tiring, chatty, too eager to share stories from their lives. Some workers are also a source of complaints with regard to the quality of the service they provide. Despite this, as explained below, personalisation makes it difficult for employers to let go of a domestic worker who has been working for them for a long time.

We will now examine the role played by personalisation, comparing informal and formal employment situations.

\section{Outside of the voucher system}

Belgian labour law guarantees migrant domestic workers working informally 'irrespective of holding a regular or irregular residence status [...] a minimum of rights to a legal minimum wage in cash, to safe work and compensation after a work-related accident, to sick pay, and to a minimum of labour protection against dismissal' (Michielsen, Willems, Nouwen, Jalhay, \& Didden, 2013, p. 49). In practice however, lawsuits are rare: workers prefer to keep good relations with employers in a labour market dominated by professional references, and legal procedures are long and uncertain due to the difficulty of proving the existence of a working relation and documenting employment conditions. Personalisation remains thus one of the only two solutions available when workers employed informally want to improve their wages and overall working conditions. The other solution is the so-called 'exit strategy', which consists in selective quitting. ${ }^{14}$ Informally employed workers who secured good arrangements with their employers oftentimes earn much more than the wages available in the voucher scheme. While average hourly wages in the informal market in Brussels oscillated between 10 and 12 euros in 2016, personalisation could result in domestic workers employed informally being paid $14-15$ euro per hour. ${ }^{15}$

Personalisation guarantees durable employment relationships in conditions of informality. Personalised relationships engender loyalty, which makes them more difficult to terminate. It seems the low occurrence of dismissals (despite the unprotected character of informal employment) is due to personalisation: employers might not be completely satisfied with the way the job is done, but once they know the worker better (which is not synonymous with liking her) and trust her, it becomes more difficult to let her go. For workers, personalisation is thus a way to counteract market-related interchangeability in order to establish long-term work relationships. Employers attach so strongly that, when a worker refuses to transition to the voucher system, there are often employers who are willing to keep paying informally (often hourly wages which are substantially higher than the price of a service voucher), precisely because of personalisation. 
The importance of personalised employment relationships for job retention in informal work is well illustrated by Małgorzata's story. This Polish cleaner, working informally in private houses across Brussels, explained how she had to defend herself to employer A against employer B, because the latter was questioning the quality of her work. She had been cleaning both the households of employer A and of employer B (at that time best friends), as well as the lawyer's office where they were both employed, for quite a long time. Then one day, employer A came to ask Małgorzata 'what she did to employer B, because employer B seemed no longer satisfied with her services' (a fact of which Małgorzata was not aware). Małgorzata had then to defend herself against those indirect criticisms, and it is only then that she understood that employer B wanted probably to get rid of her because Małgorzata was the unwilling witness of employer B's affair with employer A's husband. It is only because the relationship between Małgorzata and employer A was personalised that employer A had the idea to confront her, and the worker was able to defend herself against the accusations of employer B and keep her job. Without personalisation, the incident could have ended differently - rather than marking the end of both employers' friendship, Małgorzata would probably have lost her job.

But personalisation enables employers to exert pressure on workers, in order for them to accept longer hours or additional tasks. Employers can appeal, consciously or not, to domestic workers' private emotions (such as their concern for the care beneficiaries or sympathy for the employer) to work more for less. When she arrived from Chile, Graziela has been exploited (her own words) by the employer for whom she worked thirteen hours a day, five or six days a week. She explains that she did not see this exploitation right away, because her employer was treating her with respect despite going through a very difficult period herself:

'In fact, she was so nice that I couldn't be against her. She was so nice that I let her exploit me. [...] She was going through a very rough patch in her life, because the father of her little baby [...] left her when she gave birth, so it was a very difficult period [for her]. She told me afterwards that it was one of the most difficult periods of her life. And that I came into her home and according to her I was an angel [laugh]. Yes, I was an angel who asked for very little money in return for the work done. Of course I was an angel.' (Graziela, see above).

We will now examine the impact of the introduction of the service voucher scheme on personalisation in paid domestic work. Based on this analysis, we will draw conclusions with regard to the future of paid domestic work in Belgium after the introduction of the service voucher.

\section{In the voucher system}

The voucher system did not impact the importance of personalisation for undocumented domestic workers, because the scheme is not accessible to them.

Most interviewed domestic workers in and outside of the voucher system do not have the choice of closer or more distanced relationships with employers/clients. Indeed, paid domestic work has an important 'companionship' function for (especially elderly) employers/clients. Interviewed voucher workers explain that it is difficult to find a position ('hours') when one does not speak French, because 
elderly employers expect more than just housework: they expect domestic workers to take their time and invest emotionally in the work relationship. As a consequence, younger migrants are only partially advantaged by the fact that they learned English in school, because many employers/clients (in particular the French-speaking elderly) do not speak English.

In principle, given the exclusion of care tasks from the remit of the service voucher, we could expect that possibilities to use personalisation to manipulate workers into providing work they do not want to provide would be reduced. Our fieldwork however shows that the expectation and readiness to invest emotionally in employment relationships, in particular in the case of elderly clients, remains strong in service voucher work. Klara from Poland explains that she is working in the home of an elderly couple where her service voucher colleagues do not want to go because of the strong smell of urine:

II call her "the little stinker"... It reeks so bad there, both her and her husband are sick. [...] My boss wanted to hold her nose, because [the smell is so strong] you can't come in, but I clean there, I got used to it. This woman [the client], she is so happy when I come. [...] Once I have cleaned the place, the smell goes away. Another girl [from the same agency] went there once and she didn't want to go back. All my colleagues are complaining that it's impossible to work there. I say that I could work everywhere, it doesn't bother me. It could be worse in life.' (Klara, from Poland, informal domestic worker since the 1990s, transitioned to the voucher system after getting very frustrated with one of her informal employers)

However, formal work offers workers more avenues for defending their interests in case of a conflict with clients, although conflicts can also arise between workers and the service voucher agency. In such situations, workers feel empowered to leave clients that they consider abusive, or to find another agency. This empowerment is illustrated by Iwona's narrative:

'Before, when I did something wrong, the client would start shouting, etc., and I would cry in silence somewhere... And now, I say: "Who do you think I am to talk to me like that? If there is something wrong, there is something wrong. I can leave. You don't need to shout at me like this". But before, it was often very difficult.' (Iwona, from Poland, voucher employee since her regularisation in 2007).

The way voucher workers face conflicts reveals that transition to formal employment is empowering: they are now supported by a structure and do not feel so disempowered in case of mistreatment or conflicts with the purchasing household. They dare to say 'no' or to contradict clients, even though they still risk losing them. However, personalisation remains an important avenue for workers to defend their interests. Indeed, gains in bargaining power result from voucher workers' individual efforts, rather than structural improvements. Even voucher agencies committed to improving the working conditions of their employees have very limited possibilities to intervene in the relationship between workers and clients because agency staff is not present in clients' households and can mediate conflicts only when asked to do so by one of the parties. Agency personnel argues 
that their role is limited to raising workers' awareness of their rights and empowering them through offering training in cleaning techniques and assertiveness.

When workers lose a client or some working hours, agencies have few possibilities to top up workers' schedule: workers have to find 'hours' themselves, making use of clients' networks, which are the key to future jobs. Hence good relations with current clients are essential to finding work, whether one works informally or not. Most respondents underscored that service voucher work is in such high demand in Brussels that it is now virtually impossible to join an agency if one does not come with one's own clients. Agencies most often simply refuse domestic workers who do not bring their own clients. As explained by Katarzyna from Poland:

'-So when you go to an agency, you always have to have some hours of your own?

- I will say that now, it is certainly the case. [...] when you want to enrol into an agency, you have to have a minimum of hours - the people from the agency usually want you to have at least eighteen hours. The market is tougher now, there are much more agencies, the competition is stronger. For example, here la small town in the East Flanders region], I think there is no problem, but there are much bigger problems in Brussels - it is a big city, there is a lot of people and fewer and fewer jobs.'

(Katarzyna, from Poland, initially informal live-in childcare provider in Brussels for a Polish service voucher worker, now service voucher worker herself in East Flanders).

The Ecuadorian Ester had to leave her informal live-in employer when she needed a formal work contract to benefit from a 'regularisation through work' campaign and this employer could not afford to hire her formally. She registered in an authorized agency, but it took her some time to find 'hours', as she could not benefit from her former employer's networks.

The continued importance of networks in the voucher system explains why Filipinx workers have trouble finding enough 'hours', since their networks are mostly made up of foreign diplomats who do not make use of the voucher system. The difficulty to find clients is what makes Filipina Esmeralda say that, in searching for formal employment, she will look for hotel work rather than transition to formal domestic work in the voucher scheme:

'I would like to have a full-time job, like in a hotel or something, if I could find that. It's difficult in titres-services, because you have to find employers.' (Esmeralda, Filipina informal domestic worker in Brussels with regular status, previously overstayed a diplomatic visa).

In that sense, personalisation reinforces the segregating effects of the voucher system. Most Filipinx domestic workers arrive in Belgium as diplomatic personnel. Subsequently, they do not have much access to non-diplomat employers and often search formal employment elsewhere than in the service voucher system.

Clearly, even after transitioning to formal employment in the service voucher scheme, personalisation remains the best way to establish and cultivate long-term employment relationships. Service voucher employees who have 'their' faithful clients are more independent, since they can switch agencies more easily in case of conflict with 
management. Changes of agency are made easier by the fact that many agencies are run by managers of the same nationality as workers (often former domestic workers themselves), which eases communication. From a strategy previously developed mainly in relation to employers and co-nationals in the informal market, the importance of personalisation now extends to include agency staff in formalised paid domestic work.

\section{Concluding remarks}

This paper investigated the impact of the introduction of the service voucher system on personalisation processes in paid domestic work. We combined the results of two separate studies of paid domestic work in Belgium to demonstrate that formalisation did not reduce the frequency and importance of personalisation in this occupation. This finding has important implications in terms of future efforts to improve job quality in the sector.

Previous studies have already challenged the assumption that personalisation necessarily disappears when employment relationships in paid domestic work are triangulated (Du Toit, 2013; Meagher, 1997; Mendez, 1998). As demonstrated in this article, the frequency and importance of personalisation in paid domestic work is not reduced through formal changes in employment conditions (guaranteeing workers' access to social protection) and employment relations (formalising and triangulating previously bilateral informal worker-employer relationships). Formalisation did not substantially improve working conditions in the sector, which remains one of the most poorly remunerated in Belgium. Additionally, personalisation remains crucial for guaranteeing long-term employment (through establishing lasting relationships with current clients, agency staff and colleagues), finding new positions, as well as improving the quality of employment (for example through securing informal bonuses from clients).

Neither did formalisation alter the gendered and migrantized character of paid domestic work in Belgium. The sector continues to recruit mainly among migrants and/or women lacking professional opportunities. Better pay could also be achieved through recognizing service voucher workers' specific skills and competences. Such a recognition would undermine the social construction of domestic work as an unskilled occupation, stemming from the stereotypical notion that cleaning and care are competences acquired by every woman in the framework of her gendered socialization. We conclude that, although formalisation of paid domestic work is an important step towards improving working conditions in the sector, it is insufficient. Personalisation should not be targeted as an obstacle to the successful formalisation of the occupation. Instead, wage increases, skill recognition and policies guaranteeing domestic workers real alternatives to employment in the sector will be more successful in improving job quality in paid domestic services.

From the point of view of global gender, class and ethnic hierarchies, policy makers have to go beyond initiatives such as the service voucher system, which only formalise existing work relations in paid domestic work. Such policies do not challenge globalized gender, class, and ethnicity inequalities. On the contrary, they stimulate the endless outsourcing of domestic work, from upper- and middle-class men to their female partners, who then outsource it to class and ethnically disadvantaged women, who then in turn find even less advantaged carers and cleaners (often in their country of origin) to care for their children or elderly parents, or clean their houses while they satisfy the challenging time schedules of low-wage work in paid domestic work. 


\section{Endnotes}

${ }^{1}$ In this article, 'domestic work' is defined as unpaid housework and care giving activities performed in the household by a member thereof. Paid domestic work on the other hand is generally performed by someone who is not a member of the considered household.

${ }^{2}$ Both these incentives are lost on diplomats, a category of employers numerous in the global city of Brussels. Diplomats do not pay taxes in Belgium and have specific budgets for representation purposes. In practice, this means that this category of employers is much less concerned with the number of hours of paid domestic work they are willing to finance. As a consequence, they have fewer incentives to transition to the service voucher system.

${ }^{3}$ In this article, 'private employer' refers to households who are directly, and most often informally, employing a domestic worker, while 'client' refers to a household which uses service vouchers to pay for domestic work.

${ }^{4}$ Authorized tasks are cleaning, laundry, ironing, meal preparation and occasional sewing. Outdoor services include small errands, ironing performed in an ironing centre (if the company has one) and transport for disabled people. Care, gardening and other outdoor tasks (cleaning outside the house, car washing) are not allowed.

${ }^{5}$ They came from Poland, Portugal and Romania, sometimes years before their respective countries became EU Member States.

${ }^{6}$ South-American workers are a minority among service voucher workers, although their numbers are increasing: between 2008 and 2012, the numbers of Colombians and Ecuadorians among voucher workers doubled, while Brazilian workers increased by $87.4 \%$. South-American workers are well-represented in the informal sector, mostly because many of them lack work and stay permits (Gutiérrez \& Craenen, 2010). The increase of South-American workers in the voucher system follows the 2009 regularisation campaign, as well as other forms of regularisation. However, their presence in the voucher system is difficult to estimate, because many migrants from this part of the world apply for Belgian nationality, contrary to EU migrants.

${ }^{7}$ Polish women alone account for $8.8 \%$ of the service voucher workforce. The next two big national groups (Portuguese, 2,1\% of the total voucher scheme workforce and Romanians, 2\%) are far behind (Gerard et al., 2014, p.38). Compared to migrants from other origins, Polish domestic workers benefit from the freedom of movement and employment as EU citizens, the relative geographical proximity of their country to Belgium, a history of emigration to Belgium going as far as the arrival of Polish miners to Belgium before WWII and, more recently, ethnic networks established in the 1990s (Kuźma, 2012). Compared with migrants from other nationalities, but also with Belgian citizens of North-African and sub-Saharan descent, the demand for Polish female migrants as domestic workers could also be explained by structural privileges such as whiteness and Catholicism (for more on this, see Safuta, 2018).

${ }^{8}$ Interviewed respondents included eleven Polish women, seven migrants from the Philippines (two men, five women), as well as women from Cameroon, Chile, Ecuador, Morocco, Peru and Rwanda. 
${ }^{9}$ After Poland's EU accession in May 2004, Polish citizens were not allowed to work in Belgium without a work permit. This restriction has been lifted only on 1 January 2009. Similarly, after Romania's accession in January 2007, Belgium lifted restrictions for Romanian citizens only on 1 January 2014.

${ }^{10}$ These figures do not take into account Belgian workers with a foreign background (first and second-generation migrants).

${ }^{11}$ There is a maximum of hours a voucher system worker can provide within a year, averaging $22 \mathrm{~h}$ per week.

${ }^{12}$ 'Shift work' and substitution enable women to combine their job in Belgium with their life 'at home'. Two women make an agreement that they will do one job and rent one room alternately. When one of them works in Belgium, the other goes back to the country of origin. After a couple of weeks or months, they trade places (Grzymala-Kazlowska, 2005, p. 683).

${ }^{13}$ It is not uncommon that short-term projects turn into mid- to long-term migration, although the migrant sometimes keeps a 'temporary migration' mindset.

${ }^{14}$ 'Exit strategy' consists in quitting the jobs where employers or household members are disrespectful in their interactions with the domestic worker, jobs which do not pay well or are too straining physically or emotionally.

${ }^{15}$ On the other hand, migrant domestic workers who switched from informal live-in work to the voucher system frequently earn more than before. Indeed, average wages in informal live-in work oscillate between 800 and 1200 euros per month for 6-6,5 weekly days of live-in care giving (as of 2016). Live-out informal cleaning is better paid: in 2016, wages for a full schedule comprising 5-5,5 days of cleaning an ironing in the Brussels region (sometimes including elements of elderly care) oscillated around 1200-1600 euros per month (Safuta, 2017, p. 208).

Acknowledgements

Not applicable.

Funding

This research was supported financially by the Fonds de la recherche scientifique (F.R.S.-FNRS).

Availability of data and materials

The data used and analysed in the current study are available from the corresponding author on reasonable request, although in an anonymised form.

Authors' contributions

AS was the major contributor in writing the manuscript, providing the theoretical framework and the literature review. AS also contributed analysed interviews conducted between 2012 and 2016 across Belgium with migrant domestic workers employed informally in private households, beneficiaries of their services and experts, as well as observations on public transport, social media and other places of socialization for migrant domestic workers. BC contributed analysed interviews with migrant domestic workers, purchasing households, and authorized agencies conducted between 2011 and 2014 in the Brussels Region. An early version of the manuscript was based on a paper BC presented at the 2014 summer school "Multiple Inequalities in the Age of Transnationalization: Implications for Concepts and Methods". All authors read and approved the final manuscript.

Competing interests

The authors declare that they have no competing interests.

\section{Publisher's Note}

Springer Nature remains neutral with regard to jurisdictional claims in published maps and institutional affiliations. 
Received: 14 June 2018 Accepted: 28 December 2018

Published online: 24 April 2019

\section{References}

Ambrosini, M. (2012). Surviving underground: Irregular migrants, Italian families, invisible welfare. International Journal of Social Welfare, 21(4), 361-371.

Anderson, B. (2000). Doing the dirty work?: The global politics of domestic labour. London and New York: Zed Books.

Arnado, J. M. (2003). Maternalism in mistress-maid relations: The Philippine experience. Journal of International Women's Studies, 4(3), 154-177.

Aubert, V. (1956). The housemaid: An occupational role in crisis. Acta Sociologica, 1(3), 149-158.

Baldassar, L., Ferrero, L., \& Portis, L. (2017). 'More like a daughter than an employee': The kinning process between migrant care workers, elderly care receivers and their extended families. Identities, Global Studies in Culture and Power, 24(5). https://doi.org/10.1080/1070289X.2017.1345544.

Borgeaud-Garciandia, N., \& Lautier, B. (2011). La personnalisation de la relation de domination au travail : les ouvrières des maquilas et les employées domestiques en Amérique latine [The personalization of domination at work: maquilas' workers and domestic employees in Latin America]. Actuel Marx, 49(1), 104-120.

Camargo Magalhães, B. (2016). Transformer le travail domestique? Femmes migrantes et politique de formalisation à Bruxelles [Transforming domestic work? Female migrants and formalization policies in Brussels]. (Doctoral dissertation). Université Libre de Bruxelles.

Carbonnier, C., \& Morel, N. (2015). Taking the Low Road: The Political Economy of Household Services in Europe (pp. 1-36). In C. Carbonnier \& N. Morel (Eds.), The Political Economy of Household Services in Europe). London \& New York: Palgrave Macmillan. https://doi.org/10.1057/9781137473721.

Coser, L. A. (1973). Servants: The obsolescence of an occupational role. Social Forces, 52(1), 31-40.

Du Toit, D. (2013). From "Cinderella cleaners" to "maids from heaven": Clients' and domestic workers' perceptions of housecleaning services in Stellenbosch. South African Journal of Labour Relations, 37(1), 97-114.

Gerard, M., Romainville, J-F, \& Valsamis, D. (2014). Evaluation du système des titres-services pour les emplois et services de proximité 2013 [Evaluation of the voucher system for neighbourhood employment and services]. Brussels: IDEA Consult. Retrieved from http://www.emploi.belgique.be/publicationDefault.aspx?id=43104.

Grzymala-Kazlowska, A. (2005). From ethnic cooperation to in-group competition: Undocumented polish workers in Brussels. Journal of Ethnic and Migration Studies, 31(4), 675-697.

Gutiérrez, E., \& Craenen, S. (2010). Le Personnel Domestique: Un autre regard [Domestic Personnel: Another look]. Brussels: OR.C.A. vzw.

Hondagneu-Sotelo, P. (2001). Domestica: Immigrant workers cleaning and caring in the shadows of affluence. Berkeley: University of California Press.

Karner, T. X. (1998). Professional caring: Homecare workers as fictive kin. Journal of Aging Studies, 12(1), 69-82.

Kaufmann, J.-C. (1997). Le coeur à l'ouvrage: Théorie de l'action ménagère [Pouring heart and soul into work: The theory of household action]. Paris: Armand Colin.

Kuźma, E. (2013). Émergence d'une communauté transnationale dans l'espace migratoire européen. Analyse de la migration polonaise à Bruxelles (2002-2009) [Emergence of a transnational community in the European migratory space. Analysis of Polish migration in Brussels (2002-2009)]. (Doctoral dissertation). Université libre de Bruxelles.

Lutz, H. (2011). The new Maids: Transnational women and the care economy. London: Zed Books.

Marx, I., \& Vandelannoote, D. (2014). Matthew Runs Amok: The Belgian Service Voucher Scheme (IZA Discussion Paper No. 8717) (p. 20). Bonn: Institute for the Study of Labour (IZA). Retrieved from https://www.econstor.eu/bitstream/10419/107500/1/ dp8717.pdf

Meagher, G. (1997). Recreating"domestic service": Institutional cultures and the evolution of paid household work. Feminist Economics, 3(2), 1-27.

Mendez, J. B. (1998). Of Mops and maids: Contradictions and continuities in bureaucratized domestic work. Social Problems, 45(1), 114-135 https://doi.org/10.2307/3097146.

Michielsen, J., Willems, R., Nouwen, W., Jalhay, S., \& Didden, J. (2013). Promoting integration for migrant domestic workers in Belgium. International Migration Papers No. 116. Geneva: International Labour Office. Retrieved from https://www.ilo.org/wcmsp5/groups/public/---ed_protect/---protrav/---migrant/documents/publication/wcms_ 222293.pdf.

Molinier, P. (2009). Des féministes et de leurs femmes de ménage: entre réciprocité du care et souhait de dépersonnalisation [Of feminists and their cleaning ladies: Between the reciprocity of care and the wish to depersonalize]. Multitudes, (2), $113-121$.

Moras, A. (2013). The role of maternalism in contemporary paid domestic work. Sociology Mind, 3(3), 248-256.

Murthi, B. P. S., \& Sarkar, S. (2003). The role of the management sciences in research on personalization. Management Science, 49(10), 1344-1362

Needham, C. (2014). Personalisation, personal budgets and citizenship in English care services. Autonomie Locali e Servizi Sociali, 37(2), 203-220

Rollins, J. (1985). Between women: Domestics and their employers. Philadelphia: Temple University Press.

Romero, M. (1992). Maid in the U.S.A. New York: Routledge.

Romero, M., \& Pérez, N. (2016). Conceptualizing the foundation of inequalities in care work. American Behavioral Scientist, 60(2), 172-188.

Safuta, A. (2017). Personalization in domestic services provided informally by migrant workers in two diverging policy contexts (Belgium and Warsaw) (Doctoral dissertation). Université catholique de Louvain/Goethe-Universität Frankfurt-am-Main.

Safuta, A. (2018). Fifty Shades of White: Eastern Europeans' 'peripheral whiteness' in the context of domestic services provided by migrants. Tijdschrift voor Genderstudies, 21(3), 217-231.

Sansoni, A. M. (2009). Limits and Potential of the Use of Vouchers for Personal Services: An Evaluation of Titres-Services in Belgium and the CESU in France (Working Paper No. 2009.06). Brussels. Retrieved from http://papers.ssrn.com/sol3/ papers.cfm?abstract_id=2264194 
Service public federal Emploi, Travail et Concertation Sociale \& Centre Interfederal. (2015). "Monitoring Socio Economique. Marché du travail et origine" [Socio-economic assessment: Labour market and origin]. Retrieved from http://www.emploi. belgique.be/publicationDefault.aspx?id=44125.

Solari, C. (2006). Professionals and saints: How immigrant careworkers negotiate gender identities at work. Gender \& Society, 20(3), 301-331.

Surprenant, C. F., \& Solomon, M. R. (1987). Predictability and personalization in the service encounter. The Journal of Marketing, 86-96.

Xie, C., Hughes, J., Sutcliffe, C., Chester, H., \& Challis, D. (2012). Promoting personalization in social care services for older people. Journal of Gerontological Social Work, 55(3), 218-232.

Submit your manuscript to a SpringerOpen ${ }^{\odot}$ journal and benefit from:

- Convenient online submission

- Rigorous peer review

- Open access: articles freely available online

- High visibility within the field

- Retaining the copyright to your article

Submit your next manuscript at $\boldsymbol{\nabla}$ springeropen.com 